\title{
Bioconversion of flowers waste: Composting using dry leaves as bulking agent
}

\author{
Dayanand Sharma ${ }^{\dagger}$, Kunwar D. Yadav \\ Department of Civil Engineering, S.V. National Institute of Technology, Surat 395007, Gujarat, India
}

\begin{abstract}
At present, in India, handling of solid waste has become a major challenge for the municipal authorities. Composting of solid waste, especially organic waste, can be one of the solutions to tackle the issue of handling solid waste. The present study is focused on agitated piles composting of flower waste (FW). Five combinations of FW with dry leaves (DL) and cow dung (CD) were prepared to conduct the study. Significant changes were observed due to the addition of bulking agent. The bulking material helps to reduce the production of leachate and also to maintain the aerobic condition within the piles. The reduction of total organic carbon was $21 \%$ in $\mathrm{FW}$ composting which increased by $36.48 \%$ during the composting of FW on addition of DL and CD. On the 120th day of composting, the pH of pile five $(70 \mathrm{~kg} F W+20 \mathrm{~kg} C D+$ $15 \mathrm{~kg} \mathrm{DL}$ ) was 7.33 , electrical conductivity $2.77 \mathrm{mS} / \mathrm{cm}$, total organic carbon $26.9 \%$, total nitrogen $2.2 \%$, and C:N ratio was 12 . Appropriate proportion of waste mixture played an important role in providing favorable conditions for the microbial transformation of flower waste to stabilized compost. Finally, FW with the combination of CD and DL was found to be successful during pile composting.
\end{abstract}

Keywords: Agitated pile, Composting, Dry leaves, Flower waste, Total organic carbon

\section{Introduction}

The generation of municipal solid waste is increasing day by day and its safe disposal is a challenge for the municipal authorities. Mobilization of people from rural and urban areas and the change in their lifestyle are the main reasons for increase in the quantity of solid waste in urban areas [1]. The present study was conducted in Surat, Gujarat (India). Surat is situated on the bank of the river Tapti. It is located at $21.17^{\circ}$ north latitude and $72.83^{\circ}$ east longitude. Flower waste (FW) falls under the category of municipal solid waste. The city of Surat generates around 1,700 MT of solid waste per day [2]. Among this, the quantity of flower waste is approximately 1.5-2 MT per day. India has a variety of cultural heritage and uses flowers for decoration purposes as well as for worship in holy places and as an offering to deities. Later these flowers are thrown away as waste material. Most of the time there flowers are mixed with municipal solid waste or allowed to decay naturally. They are also at times dumped into nearby water bodies thereby leading to water as well as environmental pollution. The FW thrown into water bodies, affects the aquatic life. This might lead to the outbreak of several epidemics.
Composting is a well-known and widely used method for converting organic waste into a nutrient enriched soil product [3, 4]. Composting is the biological decomposition and stabilization of organic substrates that allows development of thermophilic temperatures as a result of biologically produced heat [5]. The end product produced is stable. It is free of pathogens, and plant seeds, and can be beneficially applied to land. These organic fertilizers are eco-friendly and do not damage natural resources. Instead they improve the fertility of the soil resulting in healthy plants. Additionally, the levels of soil organic matter, soil microbial biomass and activities are enhanced by using organic fertilizers [6].

In the composting process, bulking agents play an important role in the degradation of organic matter. It acts as a buffer and helps to maintain the $\mathrm{pH}$ within the range (6 to 8) when organic acids are produced at the initial stage of the composting process $[5,7]$. Bulking agents help to maintain aerobic conditions and moisture content within the limit (50-60\%) into the piles during the process of degradation. The presence of excessive moisture will produce leachate and the composting process slows down due to reduction of oxygen availability and porosity. Bulking
This is an Open Access article distributed under the terms of the Creative Commons Attribution Non-Commercial License (http://creativecommons.org/licenses/by-nc/3.0/) which permits unrestricted non-commercial use, distribution, and reproduction in any medium, provided the original work is properly cited.
Received September 11, 2016 Accepted March 8, 2017

${ }^{\dagger}$ Corresponding author

Email: dayanandsvnit@gmail.com

Tel: +91-261-2201522 Fax: +91-261-2221522

Copyright (C) 2017 Korean Society of Environmental Engineers 
agents such as dry leaves (DL), rice husk, saw dust, etc. provide free air passage, porosity and avoid the formation of leachate. They also help to keep the whole waste mixture moist and sustain an active microbial activity [8]. Sufficient quantities of DL are available in spring and summer season which can be stored and used as a bulking agent for the composting of FW. Various authors used DL as bulking agent and concluded that DL can easily absorb moisture content during the composting period [9-11]. Kalamdhad and Kazmi [9] used DL for the composting of vegetables waste during the rotary drum composting. Ch'ng et al. [10] used pineapple leaves for composting. The author concluded that high quality compost can be produced by co-composting pine apple leaves and chicken manure slurry. Thereby reducing environmental pollution that could result from poorly managed agricultural waste.

Much literature is available for the composting of organic waste with bulking material but there are only limited studies available on composting by using DL and FW. The present study is focused on FW composting coupled with the role of bulking agent. The study also evaluates physicochemical changes during the composting process.

\section{Materials and Methods}

The main materials used in the study were FW and cow dung (CD) with DL as bulking agent. Characteristics of each of the materials used are presented in Table 1. In this study, FW was collected from nearby temples in Surat. The quantity and composition of FW varies widely from location to location. The collected FW comprised of the flowers namely Marigold, Rose, Jasmine, and Lotus. In this study, only FW was used for composting without stems, roots and leaves. Before using these FWs for composting; the waste was segregated. Segregation was done to separate plastic, paper, thread and other waste materials. CD which was used as microbial inoculums was collected from a nearby dairy farm at Vesu in Surat. The CD was manually mixed with DL. CD contains enriched nutrients for microorganisms and enhances the degradation rate. DL were collected from SVNIT campus.
The quantity and composition of leaves varies widely from location to location and depends upon the type of plant/tree. Chopping of material was done to bring down the particle size to $3-5 \mathrm{~cm}$. The material was thoroughly mixed before being made into piles. DL were used as a bulking material to maintain the aerobic condition and arrest the leaching process of the FW during composting.

\subsection{Methodology (Agitated Pile Composting)}

The present study was conducted to monitor changes in the physico-chemical parameters by preparing five different combinations of heaps for 120 days. Waste combinations were formed into trapezoidal piles (size: length 2,100 mm, base width $350 \mathrm{~mm}$, top width $100 \mathrm{~mm}$, height $250 \mathrm{~mm}$ ) having length to base width $(\mathrm{L} / \mathrm{W})$ ratio of 6 [12]. The composting heaps were compressed to maintain the $(\mathrm{L} / \mathrm{W})$ ratio of 6 . The agitated piles contained $90 \mathrm{~kg}$ to $100 \mathrm{~kg}$ of different waste combinations and were manually turned on at intervals of $4 \mathrm{~d}$ and the samples were analyzed. Two replicates were prepared for each pile. The parameters were monitored every four days for $120 \mathrm{~d}$. Initially all the piles were covered with plastic sheet for four days. The pile combinations used are shown below:

- Combination 1 (Pile 1): 100 kg FW

- Combination 2 (Pile 2): $70 \mathrm{~kg} \mathrm{FW}+20 \mathrm{~kg} \mathrm{CD}$

- Combination 3 (Pile 3): $70 \mathrm{~kg} \mathrm{FW} \mathrm{+} 20 \mathrm{~kg} \mathrm{CD} \mathrm{+} 5$ kg DL

- Combination 4 (Pile 4): $70 \mathrm{~kg} \mathrm{FW} \mathrm{+} 20 \mathrm{~kg}$ CD + $10 \mathrm{~kg} \mathrm{DL}$

- Combination 5 (Pile 5): $70 \mathrm{~kg} \mathrm{FW} \mathrm{+} 20$ kg CD + 15 kg DL

\subsection{Parameters Monitored and Sampling Frequency}

Temperature was monitored on a daily basis using a digital thermometer throughout the composting period. Four grab samples from different locations of each pile were collected after turning the piles. Water was added to maintain the moisture content (50-60\%). Gravimetric method was used for determining the moisture content of the fresh sample. Electrical conductivity was determined by using $\mathrm{pH}$ and electrical conductivity meter. $10 \mathrm{~g}$ dried sieved sample was diluted to $100 \mathrm{~mL}$ distilled water (1:10 $\mathrm{w} / \mathrm{v}$ ) and kept for shaking in a rotary shaker for two hours. After

Table 1. Initial Physico- Chemical Characteristics of Materials Used for Composting

\begin{tabular}{lrrr}
\hline \multicolumn{1}{c}{ Parameter } & Flower waste & Cow dung & \multicolumn{1}{c}{ Dry leaves } \\
\hline $\mathrm{pH}$ & $6.76 \pm 0.10$ & $7.71 \pm 0.10$ & $6.4 \pm 0.20$ \\
Electrical conductivity $(\mathrm{mS} / \mathrm{cm})$ & $5.44 \pm 0.20$ & $4.50 \pm 0.20$ & $0.50 \pm 0.10$ \\
Moisture content (\%) & $78.25 \pm 2.00$ & $73.47 \pm 20$ & $2.00 \pm 0.50$ \\
Total organic carbon (\%) & $46.87 \pm 1.00$ & $47.97 \pm 1.00$ & $53.82 \pm 1.50$ \\
Total Nitrogen (\%) & $1.40 \pm 0.09$ & $1.50 \pm 0.06$ & $1.80 \pm 0.90$ \\
Ammonical nitrogen (\%) & $1.85 \pm 0.08$ & $0.39 \pm 0.60$ & $1.29 \pm 0.09$ \\
Carbon to nitrogen ratio & $33.47 \pm 0.08$ & $31.98 \pm 0.04$ & $29.90 \pm 0.07$ \\
Sodium (g/kg) & $1.47 \pm 0.07$ & $3.51 \pm 0.20$ & $4.25 \pm 0.10$ \\
Potassium $(\mathrm{g} / \mathrm{kg})$ & $17.30 \pm 0.30$ & $5.96 \pm 0.20$ & $2.45 \pm 0.10$ \\
Calcium $(\mathrm{g} / \mathrm{kg})$ & $4.01 \pm 0.30$ & $3.72 \pm 0.20$ & $1.25 \pm 0.10$ \\
Phosphorous $(\mathrm{g} / \mathrm{kg})$ & $3.18 \pm 0.01$ & $2.794 \pm 0.03$ & $2.217 \pm 0.02$ \\
\hline
\end{tabular}


two hours the sample was kept for half an hour for settling and then filtered through a whatman filter paper no 42. Fresh wet samples were used for the presence of $\mathrm{CO}_{2}$ evolution rate. The $\mathrm{CO}_{2}$ evolution rate was determined as described by Singh and Kalamdhad [12]. Total nitrogen present was determined by Kjeldahl method. The presence of ammoniacal nitrogen was determined by $\mathrm{KCl}$ extraction method followed by phenate method [13]. Volatile solids were determined by keeping the oven dried sieved sample in a muffle furnace for $550 \pm 2^{\circ} \mathrm{C}$ for $2 \mathrm{~h}$. The total organic carbon was calculated by dividing the volatile solids by 1.83 [14]. Heating digester (Velp scientifica DK 20) was used for digesting the $0.2 \mathrm{~g}$ sample, $10 \mathrm{~mL} \mathrm{H}_{2} \mathrm{SO}_{4}$ and $\mathrm{HClO}_{4}$ mixture (5:1) at $300^{\circ} \mathrm{C} \pm 5^{\circ} \mathrm{C}$ for two hours. The digested samples were used for the determination of total phosphorous using stannous chloride methods [14]. The concentrations of $\mathrm{Na}, \mathrm{K}$ and $\mathrm{Ca}$ were determined by using flame photometer.

\section{Results and Discussion}

FW, CD and DL contain 78.25\%, 73.47\% and 2\% moisture content, respectively. It was observed that the addition of bulking agents which is a source of carbonaceous and fibrous material helps to control excess moisture and create pore space. Singh and Kalamdhad [12] reported that the bulking agent regulates moisture content and provides free air passage. In control piles, lump formation was observed after six days which may be due to excess moisture content and lack of air passage between the particles. These lumps were converted into a hard mass after a week. Formation of leachate was also observed in combination 1 and 2 where the bulking material was not mixed. In the Combination 5 (70 kg FW + $20 \mathrm{~kg} \mathrm{CD} \mathrm{+} 15 \mathrm{~kg} \mathrm{DL})$, the moisture content at the beginning was $69.87 \%$ and it reduced to $50.75 \%$ within the next 12 days. It may be due to increase in the quantity of bulking agent $(15 \mathrm{~kg})$. Initially all the piles were covered with plastic sheets for four days. Covering of piles with plastic sheets helps in increasing the temperature inside the piles and reach the thermophilic phase in a day. The growth of fungus was observed during the first four days due to moisture and a stagnant condition. The rise in temperature inside the pile due to bacterial activity and the presence of moisture (water) converted this heat into vapour. Yadav et al. [15] reported that the vapour produced is responsible for the breakdown of tough organic material (lignin or tannin). Adequate growth of fungus was observed for 3-4 $\mathrm{d}$ in all piles. It was observed that fungus played an important role in the breakdown of lignin and tannin of organic matter. Turning of piles at interval of $4 \mathrm{~d}$ provides adequate oxygen to the piles and helps to reduce the pungent odour. It also causes a rise in temperature. Turning of piles also helps to reduce the moisture content by $2-4 \%$ [16]. After thorough mixing by the turning of heaps, the amount of moisture decreased and the temperature increased. This shows that composting processes was still proceeding very actively [17]. It was observed that in combinations 1 and 2 there was not much loss of moisture but in the piles 3, 4 and 5 due to the addition of DL the moisture content was low.

\subsection{Variation of Temperature}

Variation of temperature in the composting heap is an indication of the rate of degradation and the type of microbial biomass present during the composting process. Temperature was measured throughout the composting process at various locations of piles (top, middle and bottom). Turning of the piles at intervals of $4 \mathrm{~d}$ provides oxygen which helps to maintain the aerobic condition inside the piles and elevates temperature. The highest temperature was observed in combination $5\left(\mathrm{~T}=54.7^{\circ} \mathrm{C}\right)$. It may be due to the increased quantity of bulking agent $(15 \mathrm{~kg}$ dry leaves). The thermophilic phase (5 d) was more compared to other combinations. In combinations 1 and 2 the thermophilic phase was observed initially for 3 and 2 days, respectively. During the composting periods, it was observed that all combinations were properly sanitized and had reached active maturation phase. All the combinations had reached the thermophilic phase within 2 days. The temperature remained above $55^{\circ} \mathrm{C}$ for a period of two days, satisfying the regularity requirement for the destruction of pathogens [18]. In this study, it was observed that all combinations had satisfied the above conditions. The Fig. 1 indicates that temperature reaches the three phases namely the mesosphilic phase, the thermophilic phase and the cooling phase.

\subsection{Variation of $\mathrm{pH}$ and Electrical Conductivity (EC)}

$\mathrm{pH}$ is the one of the important parameters which greatly influenced the composting process. The $\mathrm{pH}$ range between 6.0 to 7.5 was favorable for the growth of bacteria and the value of the $\mathrm{pH}$ between 5.5 to 8.0 was favorable for the growth of fungi [19]. Fates of $\mathrm{pH}$ in different combinations are shown in Fig. 2. More acidic $\mathrm{pH}$ (5.01) was observed in combination 1 and 2 which may be due to the absence of bulking agent. In combination 1 to 5 the initial $\mathrm{pH}$ were $5.23,5.47,5.20,5.47$, and 6.21 , respectively which increased to $7.43,7.88,7.21,7.42$, and 7.33 , respectively after 120 days. Increase in the $\mathrm{pH}$ level during composting was due to degradation of protein. Degradation of short-chained fatty acids could also contribute into an increase of $\mathrm{pH}$ level [20]. Turning of the piles increased the rate of aeration and decreased the $\mathrm{CO}_{2}$ evolution rate in the compost. This may cause to increase the $\mathrm{pH}$ [21]. Composting proceeds most efficiently at the thermophilic temperature when the $\mathrm{pH}$ is approximately $8[1,22]$. After the completion of thermophilic stage, nitrification bacteria take over the process. Due to nitrification process, the $\mathrm{pH}$ decreased at the end of the composting period. The decrease in $\mathrm{pH}$ at the later stage of composting might have occurred due to the volatilization of ammoniacal nitrogen and released of $\mathrm{H}^{+}$ion as a result of microbial nitrification process by nitrifying bacteria [22, 23].

EC is a very useful parameter to check the level of salinity in the compost. EC was also responsible for phytotoxicity effects and plants growth when compost was applied to soils [20]. High salinity level in the compost can damage roots, affect nutrient uptake, limit plant-available soil water, or cause seed germination to be inhibited [24]. Variation of EC has been shown in Fig. 2. It was observed that in combinations 1 and 2 the initial electrical conductivity was 5.44 and $4.87 \mathrm{mS} / \mathrm{cm}$, respectively and finally 

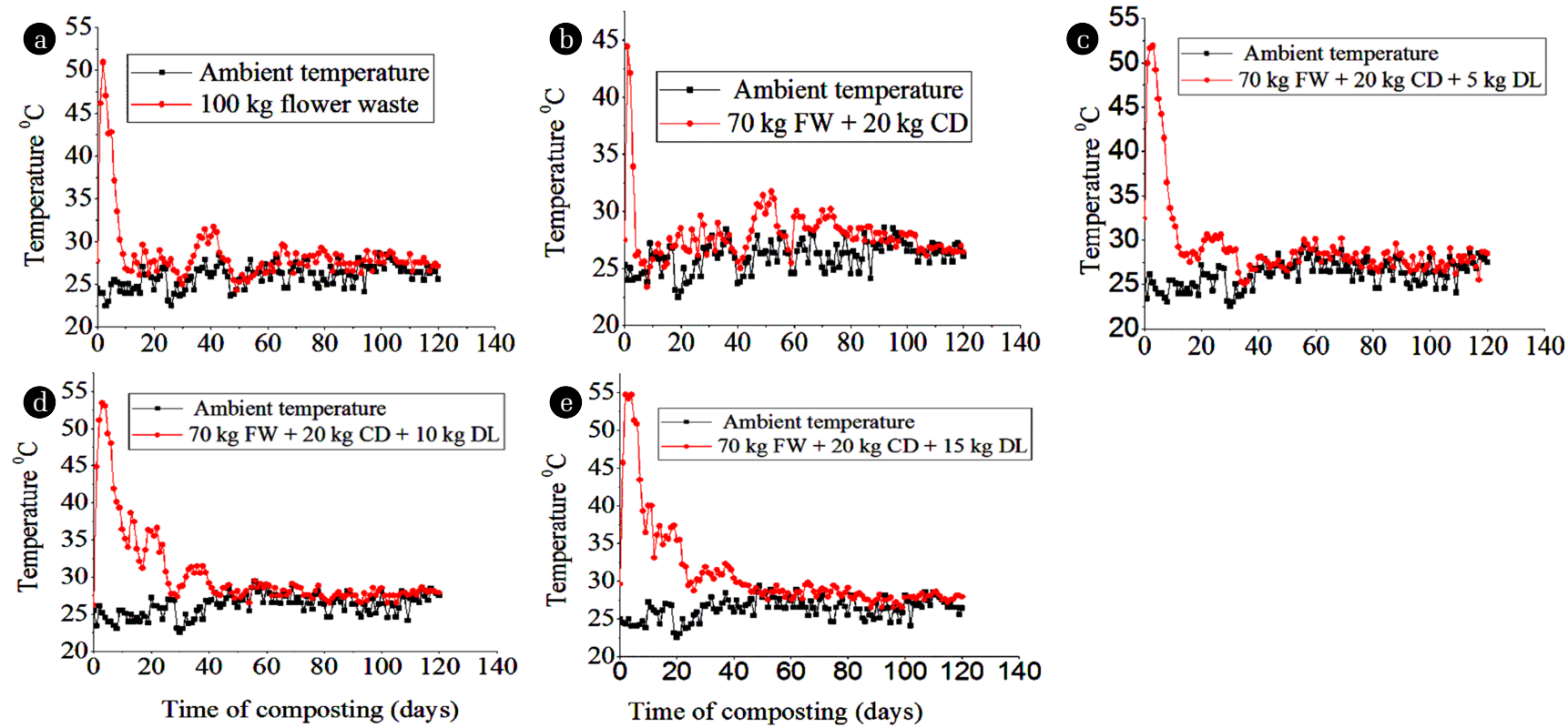

Fig. 1. Variation of temperature during the composting period.
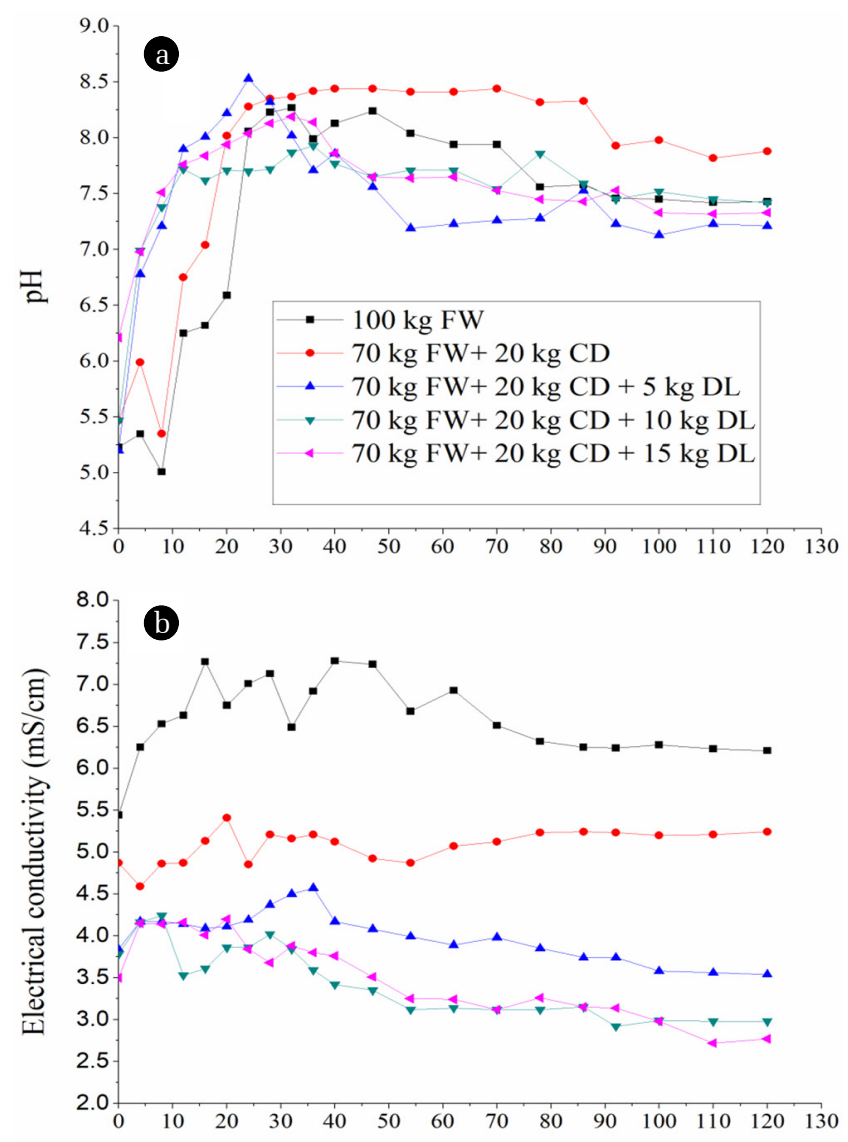

Time of composting (days)

Fig. 2. Variation of $\mathrm{pH}$ and electrical conductivity during composting period. rose up to 6.21 and $5.24 \mathrm{mS} / \mathrm{cm}$, respectively. The main reason for the increase of EC was the variation of nutrients such as $\mathrm{P}, \mathrm{K}, \mathrm{Na}$ and $\mathrm{Ca}$ in compost. Their concentration increased gradually with time, which might contribute the increase in electrical conductivity of compost. In case of combination 3, 4 and 5 the initial electrical conductivity was $3.84,3.78$ and $3.5 \mathrm{mS} / \mathrm{cm}$ decreased up to $3.54,2.98$ and $2.77 \mathrm{mS} / \mathrm{cm}$, respectively in the matured compost. During the later stage of the composting process, electrical conductivity was decreased due to the volatilization of ammonia and the precipitation of mineral salts [25]. The conversion of available salts into mineral salts was also the main reason for the decrease in electrical conductivity during the later phase of the composting process [26].

\subsection{Variation of Total Organic Carbon (TOC)}

Degradation of total organic carbon depends on the availability of easily digestible material such as cellulose and hemicellulose. The microorganisms utilized carbon as a source of energy and nitrogen for the building of the cell structures. During the degradation process of the compost, microbes utilized 60 to $70 \%$ of the carbon as $\mathrm{CO}_{2}$ and incorporated (immobilize) only 30\% to $40 \%$ of the carbon into their body as cellular components [14, 27]. Around $30 \%$ of the available carbon was utilized by the microorganisms as a source of energy. Thus the total organic carbon content is useful for estimating the age and the physical properties of the compost. Initially the total organic carbon in combinations 1 to 5 were $43.72,44.55,41.26,41.64$ and $42.37(\%)$, respectively and finally it reduced to $34.49,33.41,27.02,27.01$ and $26.91(\%)$, respectively after $120 \mathrm{~d}$. Temporal variations and reductions in total organic carbon of all combinations have been shown in Fig. 3. Higher degradation (34\% to $36 \%$ ) was observed in combina tion 4 and 5 due to the presence of bulking agents. It shows the role of bulking agent in organic carbon degradation. During 


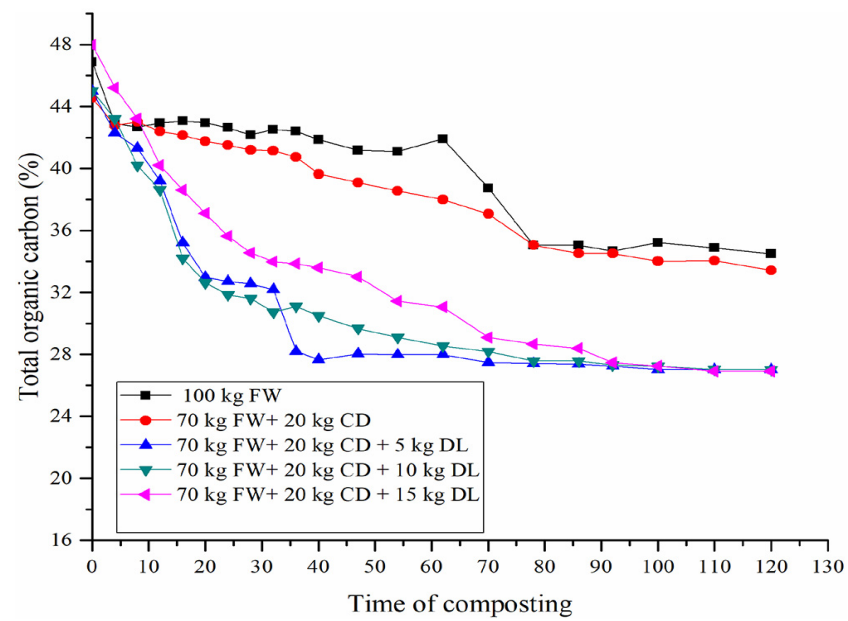

Fig. 3. Variation of total organic carbon during composting period.

the composting process, $\mathrm{CO}_{2}$ is emitted from the composting mass as a metabolic end product. Thus, the content of organic carbon decreased as the decomposition progressed [1, 28].

\subsection{Variation of $\mathrm{CO}_{2}$ Evolution Rate}

$\mathrm{CO}_{2}$ evolution rate is an important parameter to check the maturity of the compost because concentration of $\mathrm{CO}_{2}$ was reduced with maturity. Composting is a biological phenomenon in which microorganisms play an important role in the degradation of organic matter and its transformation into mineralized substances which is somewhat the same as those available in soils. The $\mathrm{CO}_{2}$ evolution rate observed in all the piles was more or less equal. The initial $\mathrm{CO}_{2}$ evolution rates were 25.32 to 26.38 (mg/gVS/d) which reduced to $0.01(\mathrm{mg} / \mathrm{gVS} / \mathrm{d})$ in all the combinations after $120 \mathrm{~d}$ of composting. $\mathrm{CO}_{2}$ evolution rate indicates maturity of the compost [29]. Bulking agents also play an important role in degradation and ultimately affect the $\mathrm{CO}_{2}$ evolution rate. In this study, a decreasing trend of $\mathrm{CO}_{2}$ evolution was observed in combinations 3, 4 and 5. The $\mathrm{CO}_{2}$ evolution rates directly shows the biological aerobic respiration rates during the composting process. It also shows the activity of the microbes during the composting process as at the end $\mathrm{CO}_{2}$ is a byproduct of compounds. It was observed that during the maturity stage of composting process $\mathrm{CO}_{2}$ evolution rate decreased. During the early stages it was observed that all the piles had high $\mathrm{CO}_{2}$ evolution rate due to the high presence of biodegradable organic matter. The decrease in the rate of $\mathrm{CO}_{2}$ evolution with composting time is a result of the reduction in metabolic activity, due to the decrease of readily available carbon [30].

\subsection{Total Nitrogen (TN) and Ammoniacal Nitrogen $\left(\mathrm{NH}_{4}{ }^{+}-\mathrm{N}\right)$ and Carbon to Nitrogen Ratio (C:N ratio)}

Table 2 shows the variation of total nitrogen, ammoniacal nitrogen and C:N ratio during the composting periods. Decreasing trends of ammoniacal nitrogen were observed during the composting process. Ammonia was generated from decomposition of nitrogenous material, i.e., proteins and amino acids [31]. Initial ammoniacal nitrogen in combination 1 was 175.95 (mg/kg) which reduced to $64.04(\mathrm{mg} / \mathrm{kg})$ after 120 days of composting. In combina-

Table 2. Variation of Ammoniacal Nitrogen ( $\mathrm{mg} / \mathrm{kg}$ ), Total Nitrogen (\%) and C:N Ratio

Ammonical Nitrogen (mg/kg)

\begin{tabular}{|c|c|c|c|c|c|}
\hline Days & $100 \mathrm{~kg}$ FW & $70 \mathrm{~kg} \mathrm{FW}+20 \mathrm{~kg}$ CD & $\begin{array}{c}70 \mathrm{~kg} \mathrm{FW}+20 \mathrm{~kg} \mathrm{CD}+ \\
5 \mathrm{~kg} \mathrm{DL}\end{array}$ & $\begin{array}{c}70 \mathrm{~kg} \mathrm{FW}+20 \mathrm{~kg} \mathrm{CD}+ \\
10 \mathrm{~kg} \mathrm{DL}\end{array}$ & $\begin{array}{c}70 \mathrm{~kg} \mathrm{FW}+20 \mathrm{~kg} \mathrm{CD} \mathrm{+} \\
15 \mathrm{~kg} \mathrm{DL}\end{array}$ \\
\hline 0 & $175.95 \pm 0.81$ & $190.1 \pm 0.78$ & $211.22 \pm 1.21$ & $231.75 \pm 1.20$ & $241.93 \pm 1.09$ \\
\hline 30 & $118.87 \pm 1.01$ & $126.41 \pm 0.57$ & $147.84 \pm 1.02$ & $149.9 \pm 0.87$ & $170.79 \pm 1.21$ \\
\hline 60 & $88.89 \pm 0.75$ & $119.78 \pm 0.87$ & $131.57 \pm 0.87$ & $140.53 \pm 0.84$ & $140.1 \pm 0.97$ \\
\hline 90 & $77 \pm 0.94$ & $91.05 \pm 0.81$ & $114.91 \pm 1.57$ & $121.47 \pm 0.89$ & $124.91 \pm 0.85$ \\
\hline 120 & $64.04 \pm 1.11$ & $87.98 \pm 0.95$ & $88.78 \pm 1.87$ & $100.77 \pm 0.76$ & $114.98 \pm 0.88$ \\
\hline \multicolumn{6}{|c|}{ Total Nitrogen (\%) } \\
\hline 0 & $1.4 \pm 0.21$ & $1.5 \pm 0.22$ & $1.6 \pm 0.20$ & $1.6 \pm 0.28$ & $1.5 \pm 0.27$ \\
\hline 30 & $1.6 \pm 0.31$ & $1.6 \pm 0.30$ & $1.8 \pm 0.16$ & $1.8 \pm 0.21$ & $2.0 \pm 0.14$ \\
\hline 60 & $1.6 \pm 0.14$ & $1.7 \pm 0.17$ & $1.9 \pm 0.18$ & $1.8 \pm 0.18$ & $2.1 \pm 0.27$ \\
\hline 90 & $1.8 \pm 0.24$ & $1.8 \pm 0.16$ & $1.9 \pm 0.15$ & $1.9 \pm 0.11$ & $2.2 \pm 0.30$ \\
\hline 120 & $1.8 \pm 0.19$ & $1.8 \pm 0.12$ & $1.9 \pm 0.17$ & $1.9 \pm 0.14$ & $2.2 \pm 0.24$ \\
\hline \multicolumn{6}{|c|}{ C:N ratio } \\
\hline 0 & $33 \pm 0.08$ & $30 \pm 1.51$ & $28 \pm 1.61$ & $28 \pm 0.87$ & $31 \pm 1.02$ \\
\hline 30 & $27 \pm 0.97$ & $26 \pm 1.72$ & $18 \pm 0.84$ & $18 \pm 1.29$ & $17 \pm 0.87$ \\
\hline 60 & $24 \pm 1.14$ & $22 \pm 0.78$ & $15 \pm 1.35$ & $15 \pm 1.27$ & $15 \pm 0.92$ \\
\hline 90 & $19 \pm 0.87$ & $20 \pm 0.84$ & $14 \pm 0.95$ & $14 \pm 0.94$ & $12 \pm 1.32$ \\
\hline 120 & $19 \pm 0.84$ & $19 \pm 1.38$ & $14 \pm 0.85$ & $14 \pm 0.86$ & $12 \pm 0.81$ \\
\hline
\end{tabular}


tion 2, the initial ammoniacal nitrogen was 190.1 (mg/kg) and at the end of the composting period it was $87.98 \mathrm{mg} / \mathrm{kg}$. Similarly in combinations 3, 4 and 5; the initial ammoniacal nitrogen were $211.22,231.75,241.93 \mathrm{mg} / \mathrm{kg}$ which reduced to $88.78,100.7$ and $114.98 \mathrm{mg} / \mathrm{kg}$, respectively. The ammoniacal nitrogen concentration decreased due to volatilization of ammonia, immobilization and assimilation of $\mathrm{NH}_{4}{ }^{+}-\mathrm{N}$ by the microorganisms and nitrification during the composting process. During the turning

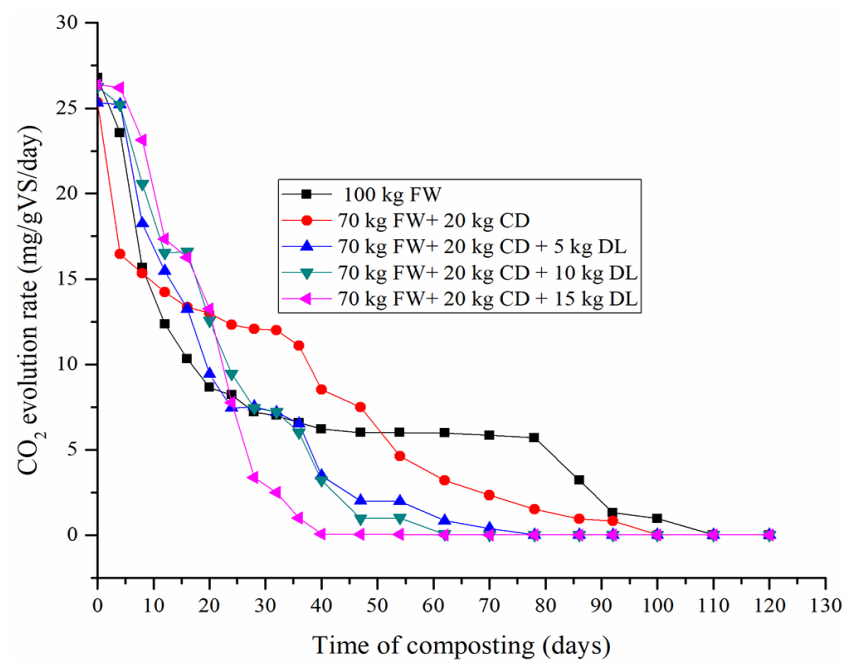

Fig. 4. Variation of $\mathrm{CO}_{2}$ evolution rate during composting period.
$\mathrm{NH}_{4}{ }^{+}-\mathrm{N}$ was released as ammonia, thereby reducing ammoniacal nitrogen. The range of ammoniacal nitrogen in matured compost as suggested by Makan and others [32], was below $400 \mathrm{mg} / \mathrm{kg}$. In the present study the concentration was very low which satisfied the maturity of the compost.

The total nitrogen in combinations 1 to 5 during the composting period were $1.4,1.5,1.6,1.6$ and $1.8 \%$, respectively which finally increased from $1.8 \%$ to $2.2 \%$. Increasing trends of total nitrogen were observed during the active thermophilic phase. It was observed that during the biodegradation process the nitrogen content increased due to the mineralization of organic matter. The nitrogen content in the final compost depends on the amount of nitrogen and $\mathrm{C}: \mathrm{N}$ ratio of the feed.

$\mathrm{C}: \mathrm{N}$ ratio was used by various researchers as the indicator for maturity of compost [16, 33, 34]. The initial C:N ratio of pile 1 was 33 which reduced to 19 at the end of the composting period. The reduction in C:N ratio was due to the reduction of total organic carbon and increase of total nitrogen during the composting period. The initial C:N ratio of pile 2 to pile 5 was 31 to 28 and it decreased to 12 to 19 at the end of composting period. The reduction of C:N ratio was due to the usage of carbon as a source of energy by the microorganisms while nitrogen was used for building the cell structure by the different group of microbes $[34,35]$. If the availability of C:N ratio is more, then the excess carbon tends to utilize nitrogen in soil to build cell protoplasm. C:N ratio ranging from 10 to 25 is sufficient for the compost maturity [12]. It was observed that in all the piles the
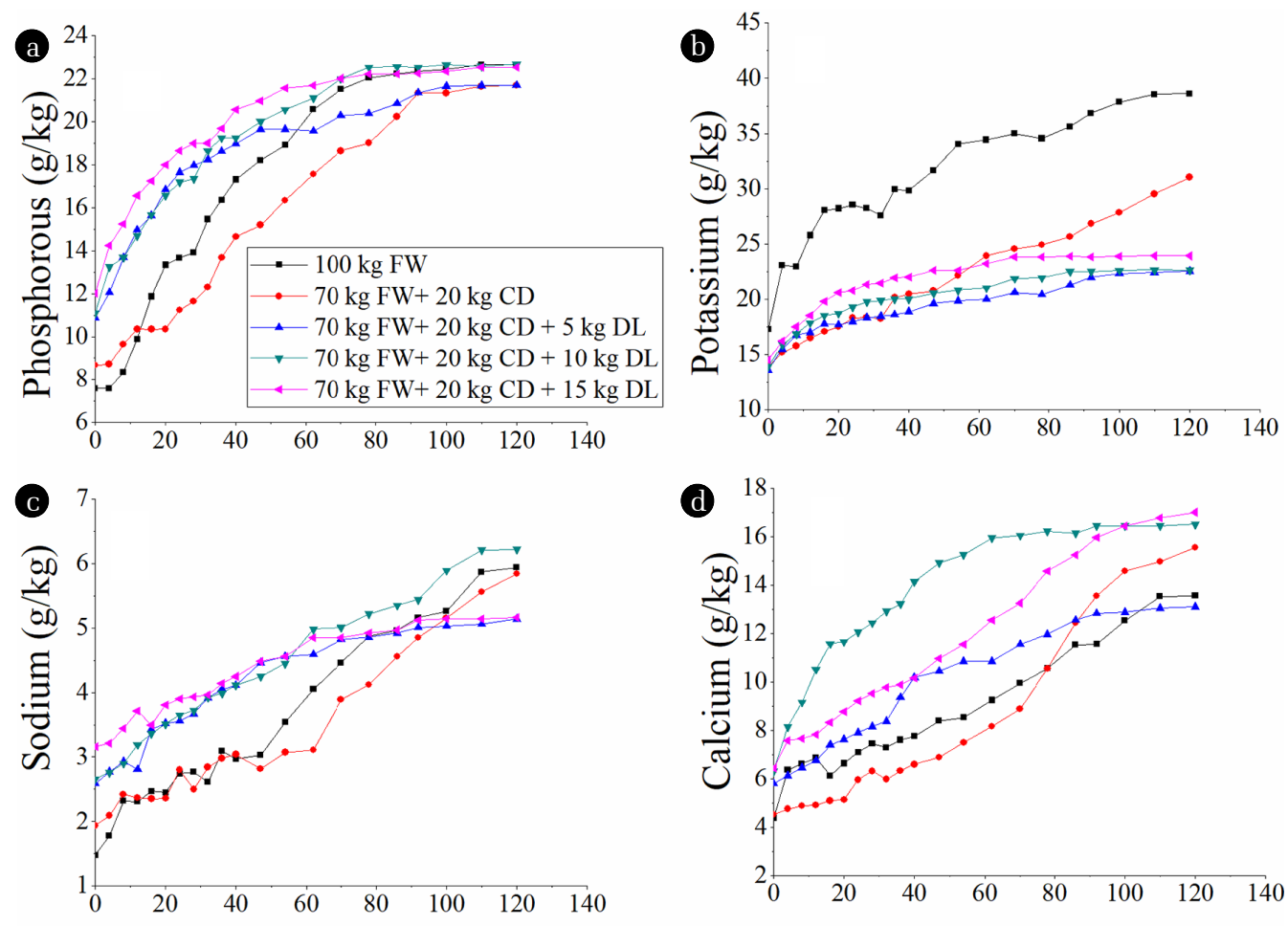

Time of composting (days)

Fig. 5. Variation of phosphorous, potassium, sodium and calcium during composting period 
C:N ratio was within the limit. Low C:N ratios releases the salts or nutrients present in the compost and helps in plant growth.

\subsection{Variation of Nutrients (Phosphorous, Potassium, Sodium and Calcium)}

The total phosphorous $(\mathrm{g} / \mathrm{kg})$ gradually increased due to the decomposition of organic matter during the composting period. The initial total phosphorous in the combinations 1 and 2 was 7.58 and $8.65(\mathrm{~g} / \mathrm{kg})$, respectively which finally increased to 22.66 and $21.69(\mathrm{~g} / \mathrm{kg})$, respectively. Similarly in the combinations 3, 4 and 5 containing DL as bulking agent the initial phosphorous were $10.88,11.11$ and $12.02(\mathrm{~g} / \mathrm{kg})$, respectively which after 120 days increased to 21.70, 22.69 and 22.54 (g/kg), respectively. There was an increase in phosphorous during the composting period due to degradation of organic matter. The phosphorous in the organic matter is used by the microorganisms for body metabolism and also for the growth of plants. Phosphorous is used by plants in soluble forms (orthophosphate ion) especially hydrogen phosphate ion $\left(\mathrm{HPO}_{4}{ }^{2-}\right)$. The increase in phosphorous concentration at the time of composting might be due to the higher rate of carbon loss that occurs when organic matter is decomposed or mineralised into $\mathrm{CO}_{2}$ or $\mathrm{CH}_{4}$.

The initial concentration of potassium in combinations 1 to 5 were $17.30,13.89,13.55,13.89$ and $14.50(\mathrm{~g} / \mathrm{kg})$, respectively which increased to 38.62, 31.06, 22.56, 22.66 and $23.95(\mathrm{~g} / \mathrm{kg})$, respectively at the end of the composting period. The unique potassium behaviour in all the piles might have been partly due to potassium assimilation and immobilisation by microbes [35]. The concentration of potassium content was high in case of all the five combinations. It shows the high inherent content in FW, suggesting that compost can be a good source of potassium fertilizer.

The concentration of sodium and calcium gradually increased which also indicates the net loss in dry mass due to the degradation of organic matter and the release of $\mathrm{CO}_{2}$ mineralisation during the composting period. In combinations 1 to 5 , the initial sodium was $1.48,1.94,2.59,2.66$ and $3.16 \mathrm{~g} / \mathrm{kg}$ which increased to 5.94 , $5.84,5.14,6.22$ and $5.16 \mathrm{~g} / \mathrm{kg}$, respectively. Similarly in combinations 1 to 5 the initial calcium were 4.36, 4.52, 5.81, 6.32 and $6.44 \mathrm{~g} / \mathrm{kg}$, respectively which finally increased to $13.56,15.56$, 13.11, 16.52 and $17.02 \mathrm{~g} / \mathrm{kg}$, respectively. Calcium and sodium are useful nutrients for plant growth. When compost is mixed with soil it increases soil acidification and makes more nutrients available to the plant. Increasing trends were observed in all the combinations and it was due to the reduction of dry mass of organic carbon, nitrogen, hydrogen and oxygen. Many studies have also emphasized on the importance of $\mathrm{Na}, \mathrm{P}, \mathrm{K}$ and $\mathrm{Ca}$ to protect the plant from diseases, pests, drought and cold [36, 37]. The production of good quality manure is essential to improve the fertility of soil thereby yielding healthy plants.

\section{Conclusions}

FW is a good source of organic waste. The degradation of FW can be increased by using bulking agent (DL). Covering of piles with polythene sheets helps in fungal growth and increase in temperature which in turn helps to break down the tough organic content of the waste. The degradation of FW without bulking agents resulted in formation of lumps, which might be due to high moisture content but lack of bulking agents. Maximum quantity (15 kg) of bulking agent (DL) was added in the FW. $70 \mathrm{~kg}$ $\mathrm{FW}+20 \mathrm{~kg}$ CD + $15 \mathrm{~kg}$ DL (combination 5) which resulted in rapid decrease of moisture content, total organic carbon (reduced to $36.48 \%$ ), final $\mathrm{pH}$ (reduced to 7.33), EC (reduced to $2.77 \mathrm{mS} / \mathrm{cm}$ ) and $\mathrm{C}: \mathrm{N}$ ratio (reduced to 12). The compost prepared from FW using DL was beneficially used as manure for the increase in rate of crop production. Increasing trends of sodium, potassium, calcium and phosphorous were observed after composting period 120 days.

\section{References}

1. Awasthi MK, Pandey AK, Khan J, Bundela PS, Wong JW, Selvam A. Evaluation of thermophilic fungal consortium for organic municipal solid waste composting. Bioresour. Technol. 2014;168:214-221

2. Surat Municipal Corporation. Solid waste management [Internet]. c2009 [cited 2 October 2016]. Available from: http://www.suratminiciapl.gov.in/Home/Index/Departments/ Helath/Solidwaste Management/Approaches.

3. Lim SL, Wu TY. Characterization of matured vermicompost derived from valorization of palm oil mill byproduct. J. Agr. Food Chem. 2016;64:1761-1769.

4. Wu TY, Lim SL, Lim PN, Shak KPY. Biotransformation of biodegradable solid wastes into organic fertilizers using composting or/and vermicomposting. Chem. Eng. Trans. 2014;39: 1579-1584.

5. Li Z, Lu H, Ren L, He L. Experimental and modeling approaches for food waste composting: A review. Chemosphere 2013;93: 1247-1257.

6. Lim SL, Wu TY, Lim PN, Shak KPY. The use of vermicompost in organic farming: Overview, effects on soil and economics. J. Sci. Food Agr. 2015a;95:1143-1156.

7. Ramdani N, Hamou A, Lousdad A, Al-Douri Y. Physicochemical characterization of sewage sludge and green waste for agricultural utilization. Environ. Technol. 2014;36:1594-1604.

8. Villaseñor J, Rodriguez L, Fernandez F. Composting domestic sewage sludge with natural zeolite in a rotary drum reactor. Bioresour. Technol. 2011;102:1447-1454.

9. Kalamdhad AS, Kazmi AA. Rotary drum composting of different organic waste mixtures. Waste Manage. Res. 2009;27:129-137.

10. Ch'ng HY, Ahmed OH, Kassim S, Ab Majid NM. Co-composting of pineapple leaves and chicken manure slurry. Int. J. Recycl. Org. Waste Agric. 2013:2;1-8.

11. Schwintzer CR, Tjepkema JD, Seekins B. Nitrogenase activity in composting horse bedding and leaves. Plant soil. 2002;242: 277-282.

12. Singh J, Kalamdhad A. Effect of rotary drum on the specification of heavy metals during the water hyacinth composting. Environ. Eng. Res. 2013:18;177-189. 
13. APHA. Standard methods for the examination of water and wastewater. 21st ed. Washington D.C.: American Public Health Association; 2005.

14. Adhikari BK, Barrington S, Martinez J, King S. Effectiveness of three bulking agents for food waste composting. Waste manage. 2009;29:197-203.

15. Yadav KD, Mistry N, Pandya D, Ganvit B. Composting of food and vegetable waste. IUP J. Environ. Sci. 2010:4;27-38.

16. Zhu N. Effect of low initial $\mathrm{C} / \mathrm{N}$ ratio on aerobic composting of swine manure with rice straw. Bioresour. Technol. 2007;98:9-13.

17. Wani KA, Mamta, Rao RJ. Bioconversion of garden waste, kitchen waste and cow dung into value-added products using earthworm Eisenia fetida. Saudi J. Biol. Sci. 2013;20:149-154.

18. Himanen M, Hänninen K. Composting of bio-waste, aerobic and anaerobic sludges - Effect of feedstock on the process and quality of compost. Bioresour. technol. 2011;102:2842-2852.

19. Amir S, Hafidi M, Merlina G, Revel JC. Sequential extraction of heavy metals during composting of sewage sludge. Chemosphere 2005;59:801-810.

20. Lim PN, Wu, TY, Clarke C, Daud NNN. A potential bioconversion of empty fruit bunches into organic fertilizer using Eudrilus eugeniae. Int. J. Environ. Sci. Technol. 2015b;12 :2533-2544.

21. Hu Z, Lane R, Wen Z. Composting clam processing wastes in a laboratory- and pilot-scale in-vessel system. Waste Manage. 2009;29:180-185.

22. Tognetti C, Laos F, Mazzarino M, Hernandez M. Composting vs. vermicomposting: A comparison of end product quality. Compost Sci. Util. 2005;13:6-13.

23. Eklind Y, Kirchmann H. Composting and storage of organic household waste with different litter amendments. II: Nitrogen turnover and losses. Bioresour. Technol. 2000;74:125-133.

24. Lim SL, Lee LH, Wu TY. Sustainability of using composting and vermicomposting technologies for organic solid waste biotransformation: Recent overview, greenhouse gases emissions and economic analysis. J. Clean Prod. 2016;111:262-278.

25. Huang G, Wong J, Wu Q, Nagar B. Effect of C/N on composting of pig manure with sawdust. Waste Manage. 2004;24:805-813.

26. Wong JWC, Mak KF, Chan NW, et al. Co-composting of soybean residues and leaves in Hong Kong. Bioresour. Technol. 2001;76:99-106.

27. Yadav A, Garg V. Feasibility of nutrient recovery from industrial sludge by vermicomposting technology. J. Hazard. Mater. 2009;168:262-268.

28. Kalamdhad AS, Kazmi A. Effects of $\mathrm{C} / \mathrm{N}$ ratio on mixed organic waste composting in a rotary drum composter. Int. J. Environ. Eng. 2009;1:187-207.

29. Varma VS, Kalamdhad A. Effect of leachate during vegetable waste composting using rotary drum composter. Environ. Eng. Res. 2014;19:67-73.

30. Iqbal MK, Shafiq T, Ahmed K. Characterization of bulking agents and its effects on physical properties of compost. Bioresour. Technol. 2010;101:1913-1919.

31. Jiang J, Huang Y, Liu X, Huang H. The effects of apple pomace, bentonite and calcium superphosphate on swine manure aerobic composting. Waste manage. 2014;34:1595-1602.

32. Makan A, Assobhei O, Mountadar M. Effect of initial moisture content on the in-vessel composting under air pressure of organic fraction of municipal solid waste in Morocco. Iranian J. Environ. Health Sci. Eng. 2013;10:3.

33. Vig AP, Singh J, Wani SH, Singh DS. Vermicomposting of tannery sludge mixed with cattle dung into valuable manure using earthworm Eisenia fetida (Savigny). Bioresour. Technol. 2011;102:7941-7945

34. Nguyen XP, Jho H, Jeong YJ, Jo YT, Islam MN, Park JH. Characterization of composted chicken manure discharged from farms in South Korea. Environ. Eng. Res. 2015;20:254-259.

35. Kalemelawa F, Nishihara E, Endo T, et al. An evaluation of aerobic and anaerobic composting of banana peels treated with different inoculums for soil nutrient replenishment. Bioresour. Technol. 2012;126:375-382.

35. Debosz K, Petersen SO, Kure LK, Ambus P. Evaluating effects of sewage sludge and household compost on soil physical, chemical and microbiological properties. Appl. Soil Ecol. 2002;19:237-248

37. Tsai SH, Liu, CP, Yang SS. Microbial conversion of food wastes for biofertilizer production with thermophilic lipolytic microbes. Renew. Energ. 2007;32:904-915. 